\title{
Evaluation of 2013 Curriculum Technical Guidance Program in Islamic Junior High School's Teachers
}

\author{
Syaharuddin*, Billy Tunas, Widodo Sunaryo \\ Pakuan University Bogor, Indonesia
}

*Corresponding Author: Syaharuddin, Pakuan University Bogor, Indonesia

\begin{abstract}
Technical Guidance program of Curriculum 2013 is the coaching to straighten up of previous curriculum to increase the professionalism, creativity, innovation, competency, and quality of Private Islamic Junior High School's -known as Tsanawiyah Madrasah-teachers at Minister of Religion in Depok City. There are many problems found to the Private Tsanawiyah Madrasah teachers to prepare a lesson plan and syllabus at Minister of Religion in Depok City referring to the implementation of Curriculum 2013. The research is done to evaluate the activities of Technical Guidance program of Curriculum 2013 to Private Madrasah Tsanawiyah teachers in Depok City were started and applied for about 2013 by Minister of Education and Cultural of Republic of Indonesia as stakeholders and standardization of implementation of curriculum 2013 in the schools or the Islamic schools. Research is using descriptive qualitative Approach with CIPP Models (Context, Input, Process, Product). Data Collective Instrument is used with the guidance of the interview, the guidance of observation, Document studied and questionnaire. Data analysis has been done through data display, data reduction, data verification and conclusion to achieve credibility level and specific objectivity of research. Results of research indicated; (1)evaluation to the need assessment program (Context) in good categories,(2) evaluation to preparation (Input) generally, in the level of good category, (3)evaluation to implementation of the program (Evaluation) in the level of good category, and (4) evaluation to output and outcome implementation program (Product Evaluation) in the level of adequate level. Recommendation of the evaluation resulted in a program can be continued sustainability with many aspects should need upgrading (amendment), and need novelty.
\end{abstract}

Key words: Technical Guidance, Curriculum 2013, Sustainable, Amendment, Novelties.

\section{INTRODUCTION}

Various kinds of efforts in improving the quality of a teacher is a must for school organizations, especially Madrasah Tsanawiyah, because improving the quality of teachers can have a good impact on student learning achievement. Teacher quality improvement programs can provide benefits for the organization. Therefore, good management of educational organization with a planned, organized, implemented, directed, guided can be evaluated. Education management of a school such as Madrasah Tsanawiyah is not only fixing infrastructure facilities but also focus on developing human resources especially teachers through the 2013 curriculum technical guidance program on Private Madrasah Tsanawiyah teachers.

Improving the quality of teachers can trigger career advancement in professionalism in carrying out their duties as an educator and educator. Educators' competence must always be improved and developed gradually and continuously because educators are the spearhead of the progress of a nation that has an important role in carrying out various tasks, functions and strategic positions in preparing Indonesia's human resources in the future, namely people with dignity smart, competitive, innovative, creative and comprehensive.

Improving the quality of teachers can be done through a series of educational and training activities, and curriculum technical guidance especially the 2013 curriculum, as organized by the Ministry of Religion in Depok City through the coordination of the Ministry of Education and Culture. Based on the background and focus of the research, the formulation of the problem in this study are:

1. What are the program needs, program policies, program objectives, program goals, and opportunities for the 2013 curriculum technical guidance program for private Madrasah Tsanawiyah teachers in the Ministry of Religion in Depok? 
2. How is the program strategy, program organizational structure, program procedures and mechanism, human resources, facilities and infrastructure, and the budget for the 2013 curriculum technical guidance program for private Tsanawiyah Madrasah teachers in the Ministry of Religion in Depok?

3. What is the appropriateness of technical guidance material, technical guidance methods and approaches, resource competence, participant enthusiasm, committee services, incentives and rewards as well as the effectiveness of the 2013 curriculum technical guidance program for private Madrasah Tsanawiyah teachers in the Ministry of Religion in the City of Depok?

4. How is the achievement of outputs program, program, outcomes program follow-up plans, and the impact of the 2013 curriculum technical guidance program on private Madrasah Tsanawiyah teachers in the Ministry of Religion in Depok?

\section{BASIC THEORY}

\section{A. The Concept of Curriculum Technical Guidelines 2013.}

In enhancing community participation in improving education in Indonesia, especially the government to educate the life of the nation and state, namely the Unitary State of the Republic of Indonesia based on the mandate of the 1945 Constitution is to organize a competency-based curriculum. Even though curriculum standards are standard, for example, the 2013 curriculum, which was previously called Curriculum Level of Education UnitS, this is the effect of every change of government cabinet, the school curriculum is always accompanied by revisions so that it confuses the community.

\section{B. Criteria for Evaluating the 2013 Curriculum Technical Guidelines}

The criteria used in this study are qualitative criteria that do not use numbers. Determination of qualitative criteria, indicators that are known criteria are components by considering ranking the indicators from an order of priority, as follows: Very Good is given a value of 5; Good rated 4; Good enough, rated 3; Poor rated as 2; and Very Poor Value 1.

\section{Program Evaluation Concept Program}

Evaluation is part of management in an organization's management system that is oriented towards implementing policies that have been designed by an organization through programs. According to Stufflebeam (2017), program evaluation is an effort to find out the level of implementation of a policy carefully by knowing the effectiveness of each component. Program evaluation is an activity that is included in the management plan of an organization and becomes a component in the system. Zhang (2011) explains that program evaluation efforts are included in a systematic method for gathering, analyzing and using the information to answer basic questions about the program. In line with this opinion, Hakan (2011) states that program evaluation is a systematic activity to collect, process, analyze and present data as input for decision making.

Based on the opinion above, it can be synthesized that program evaluation is a systematic activity to obtain data and information regarding the suitability of the program that has been designed with the implementation that has been carried out so that an alternative for further policies is obtained in determining a better program.

\section{Cipp Evaluation Model}

Stufflebeam (2017) explains that the CIPP model is based on learning by doing that is, an ongoing effort to identify and correct mistakes made in evaluation practice, to invent and test needed new procedures, and to retain an incorporate especially effective practices. The CIPP model is based on learning by doing, that is, ongoing efforts to identify and correct mistakes made in the evaluation program, to create and test new procedures needed, and to maintain or continue effective practices.

Zhang (2011) ) explains the CIPP evaluation model is designed to systematically guide both evaluators and stakeholders in posing relevant questions and conducting assessments at the beginning of a project (Context and Input evaluation), while it is in progress (Input and Process evaluation), and at its end (product evaluation). This means that the evaluation model is CIPP designed systematically as a guide for evaluators and stakeholders in asking relevant questions and conducting initial project assessments (context and input evaluation). At the same time, it is ongoing (Inputs and processes), and at the end (products). 
Hakan (2011) explains that one of the strengths of the CIPP model is, especially, that it is a useful and simple tool for helping evaluators produce questions of vital importance to be asked in an evaluation process. Evaluators can determine lots of questions for each component of the CIPP model. This means that one of the strengths of the CIPP model is that, as a simple but useful tool for evaluators to generate important questions to ask the evaluation process. The evaluator can determine many questions for each component of the CIPP model.

\section{a. (Context Evaluation)}

The Context evaluation component addresses the goal identification stage of a service-learning project. An effective service-learning project starts with identifying the needs of service providers (students) and the needs of the community. This means that the context evaluation component is directed at the stage of identifying the learning service project objectives. An effective service project starts with identifying the needs of the service provider (students) and the needs of the community. The context evaluation also aims to assess whether the goals and priorities that have been set to meet the needs of the parties being targeted by the organization (Tunc, 2010).

\section{b. Evaluation Input}

The input evaluation component can then help prescribe a responsive project that can best address the identified needs, and evaluation component input determines the project is the responsive best lead to the identification needs.

\section{c. Evaluation Process}

Stufflebeam (2017) states that in process evaluations, the evaluators monitor, document, study and report on the application of program plans. These evaluators make feedback in the implementation process of a program, and upon completion of the program, report on the continuation of the program as targeted and required. In the evaluation process, evaluators monitor, document, research and report on the implementation of program planning. The evaluator provides input into the program implementation process, after the program finishes, reports the sustainability of the program as targeted and needed.

\section{d. Product Evaluation}

According to Hakan (2011), the outcome is a product of the collection of descriptions and numerous archived judgments about the objectives, merit, and worth of the program. The outcome is the product of a set of descriptions and a number of assessments about the programme's goals, achievements, and benefits.

Rajiani (2010) explains that the purpose of product evaluation is to measure, interpret, and judge an enterprise's outcome. Its main objective is to ascertain the extent to the Evaluation and the net needs of all rightful beneficiaries. The purpose of product evaluation is to measure, interpret, and assess the results of the company (organization). The main objective is to ensure the extent to which the program being evaluated meets the needs of all rightful recipients.

\section{METHOD}

The evaluation model used in this study is the CIPP model, namely, Context, Input, Process, and Product. As for the program evaluated in this education, it is the Technical Guidance program of Curriculum 2013 that is carried out at the Private Tsanawiyah Madrasah Teachers in the Ministry of Religion of the Republic of Indonesia. The data analysis technique used in this research is descriptive qualitative. Basically, the descriptive analysis is to hold a hospitalization for a situation, also determine the frequency of occurrence of an event, with or without a hypothesis. This analysis refers to the model of Miles and Huberman which explains that there are three stages that must be carried out in data analysis, namely data reduction, data display, and conclusion: drawing and verifying (drawing conclusions/verification).

\section{RESULTS AND DISCUSSION}

\section{a. Evaluation Results on Context Components}

Based on the results of interviews with the informants above, a statement was obtained that the needs analysis was based on teacher quality, namely teacher competency and ability, the number of teachers 
applying the 2013 curriculum system, the quota of which had been determined by the Ministry of Education and Culture, that all schools in 2020 had to apply the 2013 curriculum overall, especially schools/madrasas in the Ministry Of Religion, Depok City. In this study, it was found that there were still many teachers who had not applied the 2013 Curriculum, including designing and making learning plans that were unclear and irregular. Moreover, there are still teachers who still have a diploma below the standard undergraduate or diploma, and also the suitability of teaching teachers must be linear with the subjects being taught. In the implementation of a group discussion forum (FGD), it was held to supplement or obtain complete information from sources assessed as being able to clarify information obtained from interviews and triangulation about the achievement of the results and benefits of 2013 curriculum technical guidance activities for private Madrasah Tsanawiyah Madrasah teachers in the Ministry Depok City Religion. The speakers and participants of the group discussion forum consisted of; 1) Head of Depok City Ministry of Religion Office, 2) Head of Madrasah Section of Depok City Ministry of Religion, 3) Curriculum and Evaluation Section of Depok City Ministry of Religion.

In an interview with the respondent, the Head of the Ministry of Religion of the City of Depok, a statement was obtained that the 2013 Curriculum Technical Guidance Program for private Madrasah Tsanawiyah teachers had a strong foundation or policy basis starting from the law as a legal umbrella including Ministerial regulations which became the reference operational work and technical work in implementing the 2013 curriculum technical guidance program for teachers. The law which forms the basis of the 2013 curriculum technical guidance program for teachers is Law number 14 of 2005 concerning teachers and lecturers article 8 states that teachers must have academic qualifications, competencies, educator certificates, physically and mentally healthy, and can realize national education goals. The general objective of training or guidance in implementing the 2013 curriculum is so that there is a change in the mindset of the teacher in preparing to learn, implementing learning, and evaluating learning in accordance with the evaluation of learning in the 2013 curriculum properly and correctly.

\section{b. Input Component Evaluation Results}

From the evaluation of the results on the aspects of strategy and targets, the average assessment of respondents consisting of officials and staff of the Ministry of Religious Affairs of the City of Depok and the 2013 Curriculum Technical Guidance Instructor including the Madrasah Head and Madrasah Tsanawiyah Private Madrasah teachers of the City of Depok are included in the good category, which means that some of the criteria in the determination of strategies and program targets are met that are relevant, achievable, consistent and in accordance with operational guidance documents.

From the evaluation of results on the aspects of work procedures, the average assessment of respondents consisting of officials and staff as well as the headmaster of madrasas and private Madrasah Tsanawiyah teachers and implementers of the 2013 Curriculum Technical Guidance program on Private Madrasah Tsanawiyah teachers in the Ministry of Religion The City of Depok, in the good category, means that most of the criteria in the determination of program work procedures are fulfilled, clear, workable, detailed and in accordance with operational guidance documents.

From the evaluation of results on aspects of organizational structure, the average rating of respondents consisting of private Madrasah Tsanawiyah teachers in the Ministry of Religion in Depok is included in the good category, which means that most of the criteria in determining the organizational structure of the Curriculum of 2103 Technical Guidance program the Private Madrasah Tsanawiyah teachers are met, that is clear, precise, relevant and lean by referring to the manuals that have been established.

Evaluation of results on aspects of human resource support, the average rating of respondents consisting of the Head of the Ministry of Religion and the Head of the Madrasa and the Curriculum and Evaluation Section along with the 2013 Curriculum Technical Guidance implementing committee team for Private Madrasah Tsanawiyah teachers in the City of Depok. Moderate, which means that most of the aspects of human resource support in terms of Private Madrasah Tsanawiyah teachers are realistic and sufficient.

From the evaluation of results on aspects of facilities and infrastructure support, the average assessment of respondents consisted of the Head of Service, the Head of the Madrasah Section, the Curriculum and Evaluation Section, and the teachers who participated in the 2013 Curriculum Technical Guidance on private Madrasah Tsanawiyah Teachers. Or high, which means that most of the 
criteria in the program facilities and infrastructure support are fulfilled, namely, relevant and sufficient.

Evaluation of results on the aspect of budget support, the average rating of respondents consisting of leaders and staff of the Ministry of Religion and Head of Madrasah and Private Madrasah Tsanawiyah teachers is included in the sufficient category which means that most of the criteria in the aspect of budget support have not been fulfilled which is realistic, adequacy, accountable and transparent.

Evaluation of results on the aspects of monitoring and evaluation, the average rating of respondents consisting of heads of offices, madrasah chiefs, curriculum and evaluation sections, heads of Private Madrasah Tsanawiyah and Private Madrasah Tsanawiyah Madrasah teachers in the Ministry of Religion in the City of Depok included in the meaningful category meaningful that most of the criteria for program monitoring and evaluation have not yet been met, namely relevance and consistency.

From evaluating the results of partnerships with policymakers, the average assessment of respondents consisting of the Head of the Ministry of Religion of the City of Depok, Section Head of Madrasah Ministry of Religion, Curriculum and Evaluation Section of the Ministry of Religion, Head of Madrasah Madrasah Tsanawiyah and Private Madrasah Tsanawiyah Teachers of Depok City, along with the implementation team of the 2013 Curriculum Technical Guidance in the Private City Madrasah Tsanawiyah Depok City teachers was included in the sufficient category which meant that most of the criteria in the aspects of partnerships with policymakers had not been fulfilled namely specific and relevant.

By analyzing these conditions, it is known that the cause of the problem is that partnerships with policymakers have only been made limited to the provision of 2013 Curriculum Technical Guidance and private Madrasah Tsanawiyah teachers participating in the 2013 Curriculum Technical Guidance, both guidance and target teachers have not been planned in advance. Specific and relevant.

\section{c. Process Component Evaluation Results}

From the evaluation of results on the participant identification aspects, the average assessment of respondents consisting of supervisors, executors and participants of the 2013 Curriculum Technical Guidelines to Private Madrasah Tsanawiyah Madrasah teachers in the Depok City Ministry of Religion included in both categories, which means that most of the criteria in the identification of K2103 Technical Guidance program participants are met; clear, realistic and relevant.

The main focus of the 2013 Curriculum Technical Guidance program for Private Madrasah Tsanawiyah teachers is to form teachers who understand and master the application of the 2013 curriculum, which is the most important part in preparing competent teachers to apply the 2013 Curriculum so that applying the learning system to students results in the output quality and affective ability that can foster a "character" of integrity which includes an attitude of discipline, reliable, open, empathy, leadership, and entrepreneurship.

From the evaluation of results on the 2013 Curriculum Technical Guidance scheduling aspect, the average assessment of respondents consisting of supervisors, Implementers and Participants and implementers of the 2013 Curriculum Technical Guidance program for Private Madrasah Tsanawiyah teachers in Depok City is included in the good category, which means that some the criteria for scheduling technical guidance for the 2013 curriculum are met; clear, realistic and relevant. The scheduling of the 2013 Curriculum Technical Guidance program for Private Madrasah Tsanawiyah teachers has been done well based on the availability of tools and with the competency needs of Madrasah Tsanawiyah teachers who are mentored by supervisors. The form of scheduling is a block scheduling system with a rotation system so that resources can be used optimally.

The teacher assignment aspects are in accordance with the competencies needed in the 2013 Curriculum Technical Guidance program for Private Madrasah Tsanawiyah teachers referring to the Learning Implementation Plan that has been prepared. In the learning process, the supervising teachers always refer to the development of the latest methods and use methods that are varied, innovative and appropriate to achieve the learning objectives.teacher or instructor who is a resource and becomes a benchmark and role model Guidance for participants implementing the 2013 Curriculum learning in private Madrasah Tsanawiyah Private teachers namely target teachers adjusted to the competencies of their respective Private Madrasah Tsanawiyah fields.

Based on the preliminary survey results explained above that there are problems in learning patterns based on Education Unit Level Curriculum, meaning that there are still many private Madrasah 
Tsanawiyah in Depok City have not implemented the 2013 curriculum learning system for their teachers and other related regulations as a reference for the learning process towards 2013 Curriculum Technical Guidance for Private Madrasah Tsanawiyah, Teachers. Thus, in the implementation of the 2013 Curriculum Technical Guidance for Private Tsanawiyah Madrasah Teachers in the Ministry of Religion in Depok, there are still problems in organizing the 2013 curriculum, namely the uneven application of technical guidance patterns Curriculum 2013 in the Madrasah Tsanawiyah Private City of Depok.

The aspect of monitoring and evaluation of the process of the 2013 Curriculum Technical Guidance program for Depok Private Teachers has been carried out through academic management supervision including observation, supervision, evaluation and reporting carried out by the supervising teacher. Monitoring of the participants during the technical guidance activities lasted until the participants finished implementing the 2013 Curriculum Technical Guidance program. All monitoring and evaluation results are documented and as input for the improvement of private Private Madrasah Tsanawiyah teachers, especially target teachers who are participants in the 2013 Curriculum technical guidance.

Based on the evaluation of the results of the evaluation aspects of the 2013 Curriculum Technical Guidance, the average rating of respondents which consists of supervisors, implementers and participants who manage the 2013 Curriculum Technical Guidance program for Depok Private Madrasah Tsanawiyah teachers in the good category, which means that most of the criteria in evaluating the learning outcomes of the program are fulfilled, ie clear and relevant according to procedures.

Assessment of learning outcomes or training programs for the 2013 Curriculum Technical Guidance for Private Madrasah Tsanawiyah teachers has referred to Ministry of Education No. 20 of 2007 regarding education assessment standards. The assessment begins with developing an instrument for evaluating learning outcomes that are fair, responsible and sustainable together with the preparation of the syllabus and Learning Design and job desk by educators. All assessment instruments for learning outcomes are disseminated to the teacher and periodically reviewed, based on data on failure or program implementation constraints including the findings of external examiners in order to obtain a fairer and more responsible assessment plan.

\section{d. Product Component Evaluation Results}

Discusses the product component of the implementation of the 2013 Curriculum Technical Guidance program for Private Tsanawiyah Madrasah teachers in the Depok City Ministry of Religion including aspects of achieving results and program implementation benefits for the participants of Private Tsanawiyah Madrasah Teachers participating in the 2013 Curriculum Technical Guidance program. The results and benefits or usefulness of this program, then the information obtained through interviews with private Tsanawiyah Madrasah teachers, Target Teachers or participant teachers appointed by each madrasah in determining and determining outputs and outcomes.

From the evaluation of results on the achievement of the results, the average rating of respondents consisting of the Head of the Ministry of Religion of the City of Depok, Kasi Madrasah, Curriculum and Evaluation Section, Head of Private Madrasah Tsanawiyah Madrasahs belongs to the sufficient category, which means that most of the criteria in the aspect of achieving results, it has not been fulfilled which is relevant and in accordance with the objectives of the 2013 Curriculum Technical Guidance program for Private Madrasah Tsanawiyah teachers in the Ministry of Religion in the City of Depok.

Achieving the competence of the 2013 Curriculum Technical Guidance program for private Madrasah Tsanawiyah teachers, participants have the competence to apply the 2013 curriculum in the teaching and learning process so as to produce outputs and outcomes quality in accordance with government competency standards.

Based on the evaluation of results on the aspects of the benefits of program implementation, the average assessment of respondents consisted of the Head of the Department of Religious Affairs of the City of Depok, Curriculum and Evaluation Section, Head of Madrasah Private Madrasah Tsanawiyah included in the sufficient category, which means that most of the criteria in terms of benefits program implementation, which has not been fulfilled, which is relevant and in accordance with the aims and objectives of the 2013 Curriculum Technical Guidance program for private Madrasah Tsanawiyah teachers. 
The benefits of the 2013 Curriculum Technical Guidance program for Private Madrasah Tsanawiyah teachers have been felt directly by the Private Madrasah and Madrasah Madrasah teachers themselves. Teachers have the ability and experience in the making syllabus and Learning Design as the implementation in the learning process, testing the quality of the results of the 2013 Curriculum Technical Guidance for Private Madrasah Tsanawiyah teachers in accordance with the 2013 curriculum standards established by the government and teaching experience in Private Madrasah Tsanawiyah. The benefit for madrasas is to add experience for the supervisors in terms of planning, the 2013 Curriculum Technical Guidance process to the evaluation of the final results. Benefits of the 2013 Curriculum Technical Guidance Training program have not been fully felt by the target teachers. Therefore, the responsibility of the government, especially the Depok City Ministry of Religion, to always pay attention to Private Madrasah Tsanawiyah still uses the Education Unit Level Curriculum in the learning process, so that the implementation of the 2013 curriculum is evenly distributed to all Private Tsanawiyah Madrasas in the city of Depok.

\section{CONCLUSION}

Based on the results of research and discussion, it is known that in general the Evaluation of 2013 Curriculum Technical Guidance Program in Private Tsanawiyah Madrasah Teachers in the Ministry of Religion of the Republic of Indonesia held in the good category, meaning that most of the evaluation criteria are achieved in improving services, access, and quality, education. Therefore, the 2013 Curriculum Technical Guidance Program program can be maintained and continued.

\section{BIBLIOGRAPHY}

[1] Hakan, K., \& Seval, F. (2011). CIPP evaluation model scale: development, reliability and validity. Procedia-Social and Behavioral Sciences, 15, 592-599.

[2] Rajiani, I., \& Jumbri, I. A. (2011). The cultural ecology of new public management in Indonesia. Journal of Administrative Science, 8(1), 17-31.

[3] Rajiani, I. (2010). Applying Personality Traits to Predict Loyalty and Neglect among Employees of Bank Jatim Located in 10 Big Cities of East Java (Mc Crae's and Hofstede's Theories on the effect of Culture on Personality Revisited). Jurnal Aplikasi Manajemen, 8(3), 617-622.

[4] Stufflebeam, D. L., \& Zhang, G. (2017). The CIPP evaluation model: How to evaluate for improvement and accountability. Guilford Publications

[5] Tunc, F. (2010). Evaluation of an English language teaching program at a public university using the CIPP model. Unpublished Master's Thesis). Middle East Technical University, Ankara.

[6] Zhang, G., Zeller, N., Griffith, R., Metcalf, D., Williams, J., Shea, C., \& Misulis, K. (2011). Using the context, input, process, and product evaluation model (CIPP) as a comprehensive framework to guide the planning, implementation, and assessment of service-learning programs. Journal of Higher Education Outreach and Engagement, 15(4), 57-84.

Citation: Syaharuddin, Billy Tunas, Widodo Sunaryo. "Evaluation of 2013 Curriculum Technical Guidance Program in Islamic Junior High School's Teachers" International Journal of Managerial Studies and Research (IJMSR), vol 8, no. 7, 2020, pp. 88-94. doi: http:// dx.doi.org/10.20431/2349-0349.0807011.

Copyright: (C) 2020 Authors. This is an open-access article distributed under the terms of the Creative Commons Attribution License, which permits unrestricted use, distribution, and reproduction in any medium, provided the original author and source are credited. 